\title{
Coverage of the 'Perppu Ormas' Issue by the Government vs Mainstream Online Media: Defending or Attacking the Pancasila?
}

\author{
Fajri Matahati Muhammadin \\ Department of International Law \\ Faculty of Law \\ Gadjah Mada University \\ Yogyakarta, Indonesia \\ fajrimuhammadin@ugm.ac.id
}

\author{
Nuruddin Al-Akbar \\ Department of Political Science and Government Studies \\ Faculty of Social and Political Sciences \\ Gadjah Mada University \\ Yogyakarta, Indonesia \\ nuruddin.alakbar@gmail.com
}

\begin{abstract}
July 2017, the President of the Republic of Indonesia issued a Government Regulation In Lieu of Law No. 2 of 2017 (known as 'Perppu Ormas') to revise the Law No. 17 of 2013 concerning Societal Organization (known as 'UU Ormas'), and finally legalized by the House of Representatives as a revised Law. This law is claimed to safeguard the state ideology of Pancasila by disbanding Anti-Pancasila societal organizations (SO). The first change is that previously only atheism and communism/Marxism-Leninism is considered as 'Anti-Pancasila'. Now it includes 'changing Pancasila and the constitution'. The second change is that previously to disband an SO would require a court ruling, now such court ruling is no longer required. With a doctrinal legal research, two things will be found: the first change is a minor one considering the framework of UU Ormas, while the second change is a major one because it is an issue of potential infringement of constitutional rights. Surely the Pancasila was never intended to violate a constitutional right. However, does the media do any better to defend the Pancasila? With a content analysis research, the extent of coverage Government online media on the Perppu Ormas issue will be observed. It is found that there is a tendency of Government online media to very heavily provide coverage of the first change is so heavily extensive, despite it being a minor change. It is found also that the second change receives very little coverage, despite it being a major change. With the same method, some online mainstream media is observed. It is found that there is still a tendency to highlight the first change more, but much less drastic. As shown above, this research is primarily a content analysis research but also combined with a doctrinal legal research. It is concluded that the contrast of coverage can distort and mislead the public in supporting the Perppu Ormas and newly revised UU Ormas. Further, the online media is doing a better but not sufficient role in this.
\end{abstract}

Keywords-media coverage; perppu ormas; Indonesia; human rights; Pancasila

\section{INTRODUCTION}

In the midst of the heated debates on the Jakarta governor elections and the blasphemy case of the incumbent in that election, the Indonesian Coordinating Minister for Political, Legal and Security Affairs Wiranto issued an order to disband the Hizbut Tahrir Indonesia (HTI), claiming that HTI breaches the Pancasila and caused instability. Law No. 17 of 2013 concerning Societal Organizations ('UU Ormas') does have provisions to require Societal Organizations ('Ormas)' to be consistent with Pancasila, and to disband those who are not.

Wiranto noted that disbanding requires a long procedure to disband an Ormas, inter alia court ruling, and he said that the government will go down this path on HTI [1]. However, instead of seeking a court ruling, the Government issued Government Regulation In Lieu of Law No. 2 of 2017 ('Perppu Ormas') revising the UU Ormas and disbanded HTI single handedly, which is possible due to the revisions [2]. This is claimed to defend the Pancasila.

\section{The key revisions are two points:}

The first key revision (hereinafter, First Key), UU Ormas used to provide temporary suspension as sanction for Ormas who has failed to comply with two warnings due to violation of regulations, and such sanction should be given after Supreme Court recommendation (Article 65). If the Ormas still fails to comply, it can be disbanded via court ruling (Article 70). Perppu Ormas deletes those articles.

The second key revision (hereinafter, Second Key), UU Ormas in its explanation of Article 59(4) limits the definition of 'Anti-Pancasila' to only 'atheism, communism or Marxism or Leninism'. Perppu Ormas expands it by adding '(ideologies) to replace the Pancasila and the Constitution.

This article argues that the second key revision is a minor one, yet it dominates the government online media coverage. This is while the first key revision is the more major and problematic one, yet does not enjoy much government online media coverage. Therefore this very potentially distorts the society perception towards the Perpu Ormas. In a context of democracy, the Fourth Pillar of the Pancasila is relevant, as it reads: "Democracy, lead by the wisest of wisdoms through deliberation through representation”. To support an ideal democratic system, the media is usually expected to provide a 
balance. Therefore, this research also observes similarly towards the mainstream online media.

\section{Method of ReSEARCH}

The research starts with a doctrinal legal research method which, in the language of Paul Chynoweth, “... is concerned with the formulation of legal 'doctrines' through the analysis of legal rules." [3] This is used to prove why one key revision from the Perppu Ormas is more major than the other. The research continues with a content analysis on the government online websites. All entries covering the Perppu Ormas will be searched through for the following information: how many of them actually mention the First Key at all as compared to the Second Key. Then, the same content analysis will be conducted towards mainstream Indonesian newspapers printing mainly in Bahasa Indonesia, only on their online version.

\section{RESEARCH FINDINGS}

The research findings are elaborated as follows:

\section{A. Which key Revision is More Important?}

The first key revision, as mentioned before, is essentially the deleting of the role of courts from the disbanding of Ormas. Therefore, an Ormas can unilaterally be disbanded by the Government (in this context, the executive branch only).

One must consider a number of things. First, this subject is an extension of the freedom of association, assembly, and expressing opinion as provided in Article 28E(3) of the Constitution. Article 28J(2) does provide that human rights may be limited through Laws. Perppu Ormas is equivalent to Laws as per Article 7(1)(c), Law No. 12 of 2011 concerning the Formation of Statutory Regulations, so this much is not a problem. However, second, as per Article 1(3) of the Constitution, Indonesia is based on the Rule of Law, where the law prevails over power. This can be found also as a constitutional right under Article 28D (1), and the Second Pillar of Pancasila: "Just and civilized humanity". Because of this, the enforcement of laws (including sanctioning) must be through judicial process to uphold the due process of law. This train of thought has been upheld by the authoritative interpreter of the Constitution i.e. the Constitutional Court [4]. Therefore, this key revision is a potential breach towards constitutional rights.

Regardless whether one agrees with this line of reasoning, one must accept that this first key revision is a grave issue. The second key revision is essentially an expansion of the definition of 'Anti-Pancasila'. This state ideology contains five pillars, shortly: The oneness of God, just and civilized humanity, unity, leadership by wisdom, deliberation, and representation, and social justice. One may easily deduce that the old UU Ormas scope of 'Anti-Pancasila' is a very narrow one to include only atheism, communism/Marxism/Leninism'. For example, secularism can be argued as Anti-Pancasila [5]. However, the revisions seem to not really expand except from a narrow to

${ }^{1}$ Antara News is the Indonesian government official portal, Polhukham is the office of the Coordinating Minister for Politics, Law, and Security,

Kemendagri is the Ministry for Internal Affairs, Kominfo is the Ministry of normal definition of 'Anti-Pancasila'. As explained, 'replacing the Pancasila and Constitution' is added. It is not unreasonable to argue that replacing the Pancasila is against the Pancasila. Further, the Pancasila is embedded in the Constitution as can be shown in the last paragraph of the Preamble, therefore it is not unreasonable to conclude that replacing the Constitution may therefore be Anti-Pancasila. The details of this argument may be subject to debate. However, this is a mere expansion from a narrow to normal interpretation of a rule which is generally agreed upon, i.e. 'Anti-Pancasila Ormas may not prevail'. It speaks of a limitation of constitutional rights via Law and not of enforcement, so there is no problem here.

Therefore, this second key revision not a grave one.

\section{B. Comparison of Media Coverage}

An observation was conducted to search all entries which mentioned the Perppu Ormas, from the first ever mentioned in any of those media until the time of the writing of this paper (i.e. 5 March 2018). A total of 97 entries were found from five different government online media: Antara News, Polhukham Website, Kemendagri Website, Kominfo Website, and the Kemenhukham Website ${ }^{1}$.

It shows the following results:

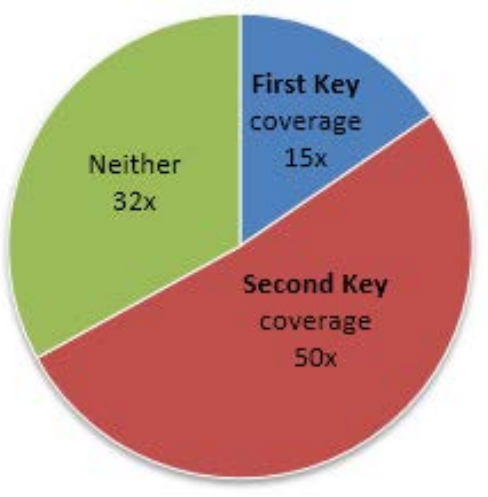

Chart 1. Government Online Media Coverage

In percentage, the total First Key coverage is $15.46 \%$ and the total Second Key coverage is $51.55 \%$. The entries covering neither is $32.99 \%$. The next observation is towards online mainstream media, and the following were chosen as the largest and most representative online media: Kompas, Republika, CNN Indonesia, BBC Indonesia, and Tempo. From 533 entries, the following results were found:

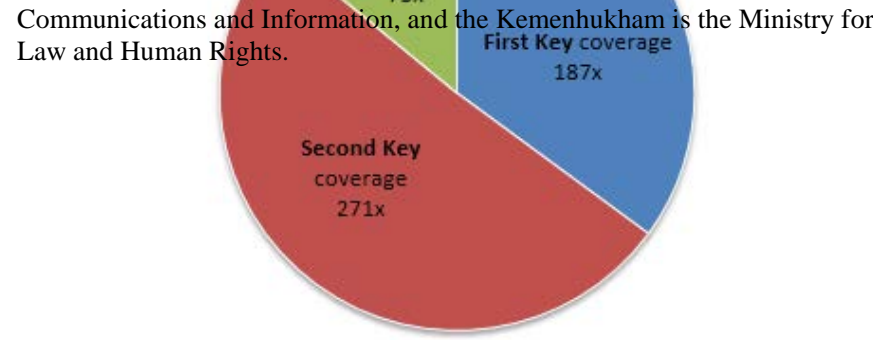


Chart 2. Online Mainstream Media Coverage

In percentage, the total First Key coverage is $35.1 \%$ and the total Second Key coverage is $50.8 \%$. The entries covering neither are $14.1 \%$.

\section{DISCUSSION}

Based on the findings shown in chart 1, there seems to be an inclination of bias $n$ the government-owned media in its effort to cover issues regarding Perppu Ormas. It appears that the government-owned media is more excited to discuss the need for a widening of the definition of anti Pancasila ideology from the previous law which includes only Marxist-Leninist ideology to now also include ideologies / movements intending to alter Pancasila and the 1945 Constitution.

Government media tend to provide a limited portion of the disappearance of court mechanisms against a mass organization accused of having Anti-Pancasila tendencies. Politically, the government's steps can be read as an effort to lead people's opinion to accept the revision of the mass organization law. Please note that the government itself who initiated the revision of Perppu Ormas so that the government is concerned that the public support their policy. But if viewed from the idea of good governance, especially transparency (information disclosure) and deliberative democratic ideas -as proposed by Habermas[6] the government's actions are not accepted.

The most important aspect of deliberative democracy is "right to know", not just "right to vote" during elections but then all forms of public policy are decided through 'closed-door negotiations' in by the formal institutions such as parliament or the government itself [7]. Deliberative democracy requires active participation of citizens in the policy-making process [8]. In the context of deliberative democratization, the availability of information is important to ensure that societies can weigh and make decisions more rationally [9]. If the information is limited and not comprehensive in a particular issue, it will also affect the people's choice. In the case of the revision of "UU Ormas", the tendency of government media to reduce information is an unhealthy phenomenon. The government reserves the right to initiate a policy but the public also has the right to participate in determining whether the policy is viable or not [10].

In contrast to the condition of the state media, if looking at the findings depicted in the chart 2 shows that the mainstream media in Indonesia is slightly less biased than state media. Meaning that the mainstream media is still not balanced in covering the revision of the Perppu Ormas, but it is at least slightly better.

From these findings, we can draw an important note that, in this issue, the mainstream media is not really fulfilling its function as the fourth pillar of democracy [11] which also relates to the Fourth Pillar of Pancasila. For information, in the conception of democracy, the media is expected to be a balancer of information that is often "covered" by the formal legal institution [12] (see also [13]). Ideally, the media can provide information to people who are far from the power circle to know what is really going on in the "closed" political space [14]. This aspect of transparency is what the media hopes to continue fighting for, especially in controversial issues, when governments (and government-owned media) tend to prefer to keep their mouths shut or to release information that is reduced in such a way that it is hard to know its validity.

Another thing that needs to be an important note, although the review presented by the mainstream media is more comprehensive than the government-owned media but if it refers to chart 2 it is undeniable that the mainstream media still gives a larger portion to the issue of the widening of the definition of Anti-Pancasila ideology (Second Key) compared to the issue of the deletion of the court mechanism in disbanding an Ormas (First Key). If this condition is not realized or tends to be ignored by the media activist, then in the future the function of the media as the fourth pillar of democracy can be questioned. The reason is when the news in the mainstream media and government media summed up, the public still get unbalanced information related to the issue of revision of UU Ormas via Perppu Ormas. The same situation also potentially occurs on other controversial issues, so that the public is harmed because of the information that comes to them is fragmentary and incomplete.

An important warning must be given towards the media to keep their existence as the fourth pillar of democracy is that they should be able to provide comprehensive information on a public issue, especially on information that is rarely displayed or even deliberately distorted away by the government and their media. Especially concerning this issue of Perppu Ormas, this is of paramount importance. It is of course important for the society to know that the definition of Anti-Pancasila ideologies has been widened (albeit from a narrow to normal definition). However, certainly the deletion of a manifestation of an important constitutional right i.e. freedom of expression and due process of law would deserve a more major spotlight.

Undistorted information is an imperative necessity if one truly wants to build true democracy instead of a pseudo one. Hopefully the media can realize their important role in improving the quality of democracy in Indonesia and also realize that when they fail to position themselves as a balancer of information, the media actually contribute to the deterioration of the quality of democracy and fulfillment of Pancasila in Indonesia.

If this problem persists, then the implications not only adversely affect the people but also the government and media itself. When the media are deemed unable to provide comprehensive, accurate, and balanced information in the eyes of some people, they will look for alternative sources of 
information that may serve as their reference in obtaining information ${ }^{2}$. No wonder social media is becoming one of the major sources of information which the people are starting to turn to [16]. Although social media coverage is less controlled than mainstream media, but in the midst of the draught of information from mainstream sources, social media has become the more preferable choice of the people to satisfy their curiosity concerning current events. So, it becomes a nonnegotiable duty for government and media activists to change themselves so that citizens return to give credence to the state and mainstream media as their trusted source of information.

\section{SUMMARY}

\section{A. Conclusion}

One important conclusion that can be drawn from the above study is the media in general is still not balanced enough in giving the portion of news related to the revision of UU Ormas. Where the media provide a larger portion in reviewing the expansion of the definition of Anti-Pancasila ideology that is prohibited in the revision of UU Ormas. While the removal of articles on the court mechanism before disbanding Ormas gets a minor portion of the discussion by the media. Although further comparable the existence of mainstream media can be interpreted more positively because at least their reviews are noticeably (though still insufficiently) less biased than the media owned by the government.

The unbalanced media position in covering the news is in fact contrary to the spirit of democracy applied in Indonesia since the fall of Soeharto's authoritarian regime. Where disclosure of information becomes important in improving the quality of democracy, because based on information spread in the public sphere that the people can determine their attitude towards an issue, including the issue of the revision of UU Ormas.

\section{B. Recommendation}

This research uses a content analysis (which is quantitative method) using only a few indicators. Yet, the results are as surprising as they are alarming. When the government is found to be biased, it turns out that the mainstream media is also so (despite not as bad). A more comprehensive qualitative method may uncover even more.

An example would be an analysis on the amount on emphasis given towards the issue. In this case of Perppu Ormas, surely it means very little if the Second key issue is mentioned but merely in passing nearing the end of the article. This is while, in the same article, the First Key is very elaborately covered and mentioned in the title. This was found in numerous data observed in the research.

Another example would be an analysis on the ties between the media and political parties. Surely, media owned by figures affiliated to certain political parties would tend to be biased: and, are there sufficient mainstream media affiliated to all interest groups? And, who are the sources interviewed by the media? Do they (deliberately) choose less credible persons for one side of an issue, and more credible persons for the other side of that issue?

Hopefully this research can be further developed to benefit all parties. The media and government should realize if what they are doing is contrary to their purpose to safeguard democracy. The people, too, should realize that something is not right in the media coverage concerning this issue. It is hoped that this research is not understood to undermine the government or mainstream media, rather it serves as a critic.

Especially in such an issue where the Government passes a law claimed to defend but potentially attacks the Pancasila instead, surely other parties such as the media is expected to balance them out by countering. What has happened is much regretted, and it has to be fixed. No solution comes without first identifying and acknowledging the problem.

\section{ACKNOWLEDGMENT}

This paper is presented under funding from Lembaga Pengelola Dana Pendidikan Republik Indonesia, as part of the Beasiswa Pendidikan Indonesia scholarship for the first author's Ph.D study at the Ahmad Ibrahim Kuliyyah of Laws, International Islamic University of Malaysia. The authors would like to thank Novi Inayatun Nadziroh as research assistant for her irreplaceable assistance in data collection.

\section{REFERENCES}

[1] E. Daryanto, "Wiranto: HTI Berbadan Hukum, Pembubaran Lewat Jalur Peradilan [HTI has Legal Entity, Dissolution Conducted by Court]," Detiknews, May. 8, 2017, [Online], Available: $\quad$ https://news.detik.com/berita/d-3495586/wiranto-htiberbadan-hukum-pembubaran-lewat-jalur-peradilan. [Accessed Dec. 13, 2017].

[2] A. N. K. Movanita, "HTI Resmi Dibubarkan [HTI Officially Dissolved]," $\begin{array}{llll}\text { Kompas.com, Jul. 19, 2017, } & \text { [Online], }\end{array}$ Available: http://nasional.kompas.com/read/2017/07/19/10180761/htiresmi-dibubarkan-pemerintah. [Accessed Dec. 13, 2017].

[3] P. Chynoweth, "Legal Research.” In Advanced Research Methods in the Built Environment, Andrew Knight and les Ruddock, Eds., West Sussex: Wiley-Blackwell, 2008, p. 29.

[4] Indonesian Constitutional Court, Decision No. 6-13-20/PUU-VIII/2010, para 3.13.

[5] F. M. Muhammadin, “Aku Pancasila dan Aku Bingung [I am Pancasila and I am Confused,” Republika, Nov. 7, 2017, [Online], Available: $\quad$ http://www.republika.co.id/berita/jurnalismewarga/wacana/17/11/07/oz1rsw291-aku-pancasila-dan-aku-bingung. [Accessed Dec. 13, 2017].

[6] J. Steiner, The Foundations of Deliberative Democracy: Empirical Research and Normative Implications, Cambridge: Cambridge University Press, 2002, p. 125.

[7] X. Huang, Politics in Pacific Asia: An Introduction, London: Palgrave Macmillan, 2009, p. 221.

[8] L. B. Tremblay, "Deliberative Democracy and Liberal Rights,” in Ratio Juris. vol. 14, no. 4, p. 425, December 2001.

[9] A. Pathak, Legal Aspects Of Business, 4th ed., New Delhi: Tata McGrawHill Education Private Limited, 2010, p. 589.

[10] R. A. A. Wattimena, Melampaui Negara Hukum Klasik [Surpasess Classical Law State], Yogyakarta: Kanisius, 2007, p. 125.

\footnotetext{
2 For example, according to Gallup polls, over $60 \%$ of Americans don't trust mainstream media. See [15].
} 
[11] R. Sugihartati, Perkembangan Masyarakat Informasi \& Teori Sosial Kontemporer [Development of Information Society and Contemporary Social Theory], Jakarta: Kencana, 2014, p. 45.

[12] M. Fikri AR., Jurnalisme Kontekstual [Contextual Journalism], Malang: UB Press, 2016, p. 33.

[13] R. Karklins, The System Made Me Do it: Corruption in Post-communist Societies, New York: M.E. Sharpe, 2005, p. 109.

[14] T. Besley, R. Burgess, and A. Prat, "Mass Media and The Political Accountability" in The Right to Tell: The Role of Mass Media in Economic Development, Washington D.C.: World Bank, 2002, p. 45
[15] L. Morales, “U.S. Distrust in Media Hits New High”, Gallup, Sep. 21, 2012, [Online], Available: http://news.gallup.com/poll/157589/distrustmedia-hits-new-high.aspx. [Accessed Apr. 18, 2018].

[16] J. Hempel, “According To Snopes, Fake News Is Not The Problem”, Gallup, Nov. 16, 2016, [Online], Available: http://news.gallup.com/poll/157589/distrust-media-hits-new-high.aspx. [Accessed Apr. 18, 2018]. 